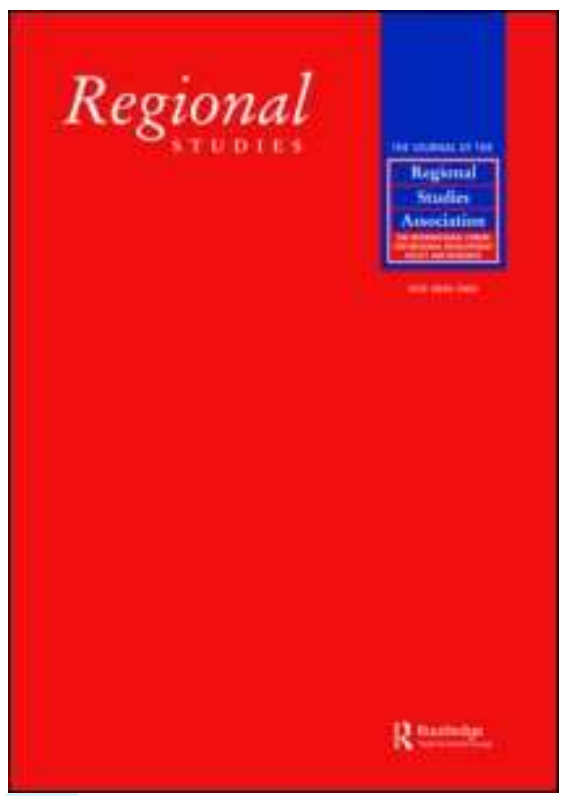

\title{
New trends of suburbanization in Beijing since 1990: from
} government-led to market-oriented

\begin{tabular}{|r|l|}
\hline Journal: & Regional Studies \\
\hline Manuscript ID: & CRES-2006-0155.R3 \\
\hline Manuscript Type: & Main Section \\
\hline JEL codes: & $\begin{array}{l}\text { P25 - Urban, Rural, and Regional } \\
\text { Economics|Housing|Transportation < P2 - Socialist Systems and } \\
\text { and Regional Economics, R14 - Land Use Patterns < R1 - General } \\
\text { Regional Economics < R - Urban, Rural, and Regional Economics }\end{array}$ \\
\hline Keywords: & suburbanization, city-region, spatial pattern, Beijing \\
\hline
\end{tabular}

\section{SCHOLARONE Manuscripts}




\title{
New trends of suburbanization in Beijing since 1990: from government-led to market-oriented
}

\begin{abstract}
Acknowledgement
This research is funded by the National Natural Science Foundation of China (40501023). We are grateful to the Beijing Planning Commission for assistance with field visits and data. We also thank Ms Wang Xiaoguang, Chen Yang and Mr Lan Zongmin for assisting the research. The constructive comments from anonymous reviewers are acknowledged.
\end{abstract}

\begin{abstract}
Since the 1990s suburbanization has been continuing in China along with the deepening of market transition. The process of suburbanization has gone beyond purely government-initiated relocation of households and polluting industries. Based on the newest population census, this paper identifies some major new trends of suburbanization in Beijing. The new round of suburbanization has been driven by the construction of suburban villas and affordable housing, rising private car ownership, the decentralization of industry, and the development of large suburban shopping malls and retail parks. Passively relocated households are no longer the dominant source of suburbanization. Suburbanization in Beijing has evolved into a new stage of more market-oriented development in the suburbs.
\end{abstract}

Key words: suburbanization, population census, Beijing, China

\section{Introduction}

The purpose of this paper is to reflect on the similarities and differences in the operation of the processes underpinning urbanisation in China and the West. Using the newest population census, we argue that the startling differences identified in earlier research (e.g. Zhou \& Ma 
2000) began to fade off. The new round of suburbanisation since 1990 has seen more market-driven rather than government-led processes: residential suburbanization is driven by rising car ownership and preference for suburban villas and quality housing; industrial relocation is facilitated by the development of suburban industries; and retail suburbanisation began to appear in the form of large shopping malls and retail parks. This is not to suggest that Chinese suburbanisation takes an identical form in the West. However, the differences are related to the different stages of suburbanisation rather than being caused by the dichotomy of market and planned economies.

The literature of 'new suburbanisation' (e.g. Garreau 1991; Stanback 1991; Knox 1993) suggests the stage of suburbanisation since the 1980s in the West (especially the USA) is different from predominately residential suburbanisation in the 1960s and 1970s. Chinese suburbanisation began from a very different starting point. Suburbanisation started from government sponsored industrial relocation before the substantial land and housing reforms began. Now, the process of suburbanisation has seen not only the relocation of industries and workers from the city to the suburbs but also the development of a full-fledged suburban economy.

The paper uses the city of Beijing as an empirical case. It examines residential, industrial and retail suburbanization trends. The structure of the paper is as follows. In sections 2 and 3, the literature of suburbanization in the West and China is reviewed. Then, in section 4, suburbanization between 1990 and 2000 is analysed in terms of changes in population and population densities. Section 5 describes new trends of suburbanization and consequences of suburbanization. Section 6 is the conclusion.

\section{Suburbanization and 'new suburbanization' in the west}

Suburbanization is a process through which population shifts from the city to suburbs (Johnson, 1974; De Vise, 1976; Stanback \& Knight, 1979; Scott, 1982; Hall, 1984; Gad, 1985). However, the process of suburbanization exerts a significant impact on everyday life, commuting and work. In this sense, the United States is now a suburban country rather than an urban country 
(Palen, 1997: 198). The driving forces of suburbanization changed in the 1980s. T. Champion (2001: 148) states, "Originally, suburbanization was dominated by the housing needs and aspirations of the family, with the emphasis very much on the male breadwinner and on the healthy space in which the mother could devote her time to bringing up her children and providing for her husband. As a result, residential suburbanization and the dominant process of population redistribution formed the first tidal wave of suburbanization in Western countries after World War II."

Since then, the decentralization of manufacturing, commerce, retail, and office work has brought about new waves of suburbanization in Western countries (T. Champion, 2001; Coffey \& Shearmur, 2002). Industrial suburbanization is attributable to two factors, one making the central city increasingly unattractive for industry, and the other making peripheral locations attractive (Scott, 1982). Industrial suburbanization has brought many consequences, such as the reduction in the central city's tax base, wide-ranging repercussions in terms of the spatial distribution of employment opportunities, damage to employment opportunities for black people, and increases in the length of the journey to work (De Vise, 1976; Cadwallader, 1996).

One of the major changes in the pattern of retailing since World War II has been the suburbanization of commerce, and in particular, the emergence of large, planned shopping centres (Cadwallader, 1985: 97). Until the mid-1980s, shopping centres became increasingly larger, incorporating other services besides retailing, and regional-level shopping centres had become catalysts for the overall suburbanization process, acting as local growth poles (Cadwallader, 1996; Jackson, 1985). Palen (1997: 143) thinks, "If the dominant urban symbol for the beginning of the twentieth century was the skyscraper, the dominant symbol for the beginning of the twenty-first century is the suburban shopping mall.”

Office functions also followed the trend of suburbanization. The facts are that the economics of real estate and a revolution in communications have changed the circumstances that office companies depend on; that insurance companies, bank branches, regional sales staffs, and doctors' offices have reduced their costs and increased their accessibility by moving to 
suburban locations; and that many companies are balkanizing their accounting departments, data-processing divisions, and billing departments, which can be far away from the CBD; all these facts have driven the development of office suburbanization (Jackson, 1985: 267-268). The process of office decentralization differs, depending on the type of office function and its hierarchy, and the decentralization of office locations to the suburbs has two aspects: one is to relocate, and the other is to develop new business in the suburbs (Castells, 1989). White-collar office jobs have also been suburbanized. In short, the exodus of manufacturing, shopping and offices has created a multi-nucleated pattern of outer suburban centres (Pallen, 1997: 198-199).

Since the 1990s there has been an increase in the literature of suburbanization (Stanback, 1991; Garreau, 1991; Bier \& Howe, 1998; Jordan et al., 1998; A. G. Champion, 2001; Graves, 2003). In the 1990s, intra-metropolitan distributions of economic activities and employment became the major focus of research, including edge cities (Garreau, 1991), new suburbanization and magnet areas (Stanback, 1991), agglomeration and dispersion of high-order services (Coffey et al., 1996; Coffey \& Shearmur, 2001, 2002), suburban employment centres (McDonald \& Prather, 1994; McDonald, 2000; Small \& Song, 1994), the polycentric structure of the metropolitan region (Bontje, 2001; A. G. Champion, 2001), and the geographies of producer services (Coffey, 2000).

Stanback (1991: 120) developed the concept of 'new suburbanization' to suggest the latest stage of suburbanization: "major new centres of business consumer and social services have developed, giving rise to agglomeration economies and posing new challenges to the social and economic structure of the central city." New suburbanization - with its suburban downtowns and edge cities - is increasingly being seen as challenging city centres and threatening to turn the traditional metropolitan area inside out, and the distinction between urban and suburban has become increasingly blurred across the more developed world (T. Champion, 2001: 150). In western suburbanization, the government has played a considerable role, sometimes directly (such as the UK's New Town Programme from 1946), but also sometimes indirectly (such as the USA's public-sector freeway construction and tax relief on home purchase). However, 'new suburbanization' is increasingly driven by market forces in the post-industrial city. 


\section{Suburbanization in China}

Recently there has been a growing literature of urban development in China. The literature contributes to the understanding of suburbanization in China, including migration and residential mobility (Li, 2001; Fan, 2001 \& 2002), social structure and sociospatial differentiation (Lo, 1994; Hu \& Kaplan, 2001; Gu \& Wang, 2005), housing development and reform (Logan et al., 1999; Wang \& Murie, 1999; Li, 2000; Huang \& Clark, 2002), urbanization and suburbanization (Wang \& Zhou, 1999; Zhou \& Ma, 2000; 2003), new changes of urban process and landscape (Logan, 2001), and internal structure and restructuring (Yeh \& Wu, 1995; Ning \& Yan, 1995; Wang \& Wang, 1998), and governance and administrative changes (Zhang \& $\mathrm{Wu}, 2006$ ). But there is still a lack of up-to-date research on suburbanization.

Research on suburbanization in China was developed in an earlier paper by Zhou and Ma (2000), emphasising the passive side of suburbanization. However, the driving forces have changed since 1990. Figure 1 describes the new forces which transform the process of suburbanization from 'passive' government-led to 'active' market-oriented. The first new force is active residential relocation in the suburbanization process. In the 1980s, households could not make relocation decisions. They were relocated by the government through the renewal of old urban areas. In the 1990s, more and more households moved out of the core to the suburbs, partly because of inflated house prices in the core and partly because of a greener environment in the suburbs (Huang \& Clark, 2002; Feng \& Zhou, 2004a, Feng, 2004). Second, because of the land market, industrial enterprises decided to relocate so as to obtain additional money from land sales and more space in the suburbs for production. The relocation of industries is implemented through the land market. Many enterprises are willing to be relocated or in fact seek relocation by themselves. This is very different from previous government-led factory relocation. Third, commercial suburbanization, mainly caused by the construction of large shopping centres in the suburbs, has shifted the pattern of consumption towards the suburbs. With the construction of ring roads and fast roads, the accessibility of the suburbs is enhanced. 
New trends of suburbanization include social driving forces as well as economic forces. Market-oriented active relocation is related to social polarization in the city (Gu \& Kesteloot, 1997) and the changing residential preferences of some residents. There was a well-known saying in the past, "preferring a bed in the central city to a house in the suburbs" (Wang \& Zhou, 1999), indicating that many residents were unwilling to move out of the core because of the lack of basic facilities in the suburbs. However, suburban landscapes have changed since 1990. Households began to seek a better environment and a lifestyle based on the private car, while low-income households have had to buy affordable housing in suburbs because it is cheaper there. The suburbs are becoming more attractive than they were in the 1980 s.

\section{Suburbanization in Beijing between 1990 and 2000}

As the capital of China, Beijing has greatly expanded since 1949. The master plan in 1958, under the influence of the Soviet town-planning model, aimed to transform the consumer city into a producer city. With much emphasis on industrial development, twelve industrial-residential clusters were designed in suburbs, each of which was led by a key state work unit to unify working and living (Gu et al., 2005; Sit, 1995; Yeh \& Wu, 1995). In 1983, the master plan specified that government, research institutes and universities should expand into the suburbs. Satellite towns were planned in the 1980s (Beijing Planning Committee, 1983). Suburbanization thus started in Beijing, but was mainly driven by the government plan. In the literature, it has been argued that suburbanization in China is very different from that in North America (Zhou \& Ma, 2000; Zhou \& Meng, 2000; Wang \& Zhou, 1999; Zhou, 1996), because intra-urban residential moves in Beijing were not based on households' residential preferences. Private car ownership was not common in China. But suburbanization began to accelerate in the 1990s, as shown in the city of Hangzhou (Feng \& Zhou, 2005). With large-scale construction of ring roads, highways and fast roads, the development of villas, affordable housing schemes and second homes, the formation of a land market, speeded-up industrial relocation, and the emergence of shopping malls in suburbs, suburbanization in Beijing has seen some new trends. Administrative annexation under a new mode of governance has also been triggering the expansion of urban areas towards suburban counties (Zhang \& Wu, 
2006). The new trends present active suburbanization initiated by residents, industrial enterprises and retail companies. This is different from the passive form of relocation (active and passive forms of suburbanization are defined based on whether the decision-making is bottom-up from land users or top-down from the government).

This study uses population censuses because they are the most accurate and comprehensive data so far available. Because census data are collected based on residence, it is not entirely proper to use census data to describe employment locations. In China, five population censuses were carried out up until 2000; these were the first in 1953, the second in 1964, the third in 1982, the fourth in 1990, and the fifth in 2000. Data from the third, fourth and fifth national population censuses are used in this study.

The administration structure of Chinese cities is complicated because of the division between the urban and the rural in the planned economy (Ma \& Cui, 1987). The city region of Beijing consists of the metropolitan area (urbanized area) and rural counties. The metropolitan area can be further divided into the core urban districts (old urban area), the inner suburbs and the outer suburbs (Figure 2). The continuous built-up urban area roughly covers the core and inner suburbs. The rural counties outside the metropolitan area are defined as the 'level two outer suburbs', which are basically rural areas outside the commuting field. The zones are customarily defined according to the administrative system. The metropolitan area consists of 14 districts. Urban districts are different from counties in that the latter are rural administrative units. Along with urban expansion, many counties in Chinese cities have been annexed into urban districts.

The core urban area of Beijing, comparable to the city centre, is composed of four districts: Dongcheng, Xicheng, Chongwen and Xuanwu; the inner suburbs include the four districts of Chaoyang, Fengtai, Haidian and Shijingshan; and the outer suburbs include the ten districts / counties of Tongzhou, Daxing, Fangshang, Mentougou, Changping, Shunyi, Yanqing, Huairou, Miyun and Pinggu (Sun, 1992; Zong, 2002). In Beijing, ring roads are also often used for spatial reference, but for the study of suburbanization and for the sake of compatibility with 
census data, administrative boundaries are better.

Beijing began its suburbanization in the 1980s and accelerated its steps in the 1990s. Suburbanization occurred intensively in the inner suburbs in the 1990s. During the period from 1990 to 2000 , the population of the core decreased from 2.337 million to 2.115 million, with a net loss of 9.5\%. In comparison with the period from 1982 to 1990, the core lost 82,000 people with a growth rate of $-3.38 \%$. The decline of population in the core became much more obvious in the 1990s. Because the natural growth rate of population in the core of Beijing was positive in these periods (Zhou, 1996), the decline of population in the core signifies the relocation of residents to suburbs. The population of the inner suburbs increased from 3.989 million in 1990 to 6.389 million in 2000 , an absolute growth rate of $60.15 \%$. Compared with a population increase of 1.149 million, a growth rate of $40.46 \%$ in the period from 1982 to 1990 , the population of the inner suburbs in Beijing increased significantly in the 1990s. The population of the outer suburbs increased from 4.494 million in 1990 to 5.066 million in 2000, with a lower growth rate than in the 1980s (Table 1). In the 1980s, the difference in population growth between level one (urbanized) suburbs and level two (rural exurb) suburbs was not obvious. In the 1990s fast population growth occurred in the level one outer suburbs. The inner suburbs gained much more population in the 1990s, with the population growth rate increasing by about $20 \%$. More population from the core moved out, mainly to the inner suburbs, but some to the outer suburbs (especially level one).

Beijing's suburbanization mainly occurred in the inner suburbs. Figures $3 a$ and $3 b$ present the distribution of population growth rates in the Beijing metropolitan area during the periods from 1982 to 1990 and from 1990 to 2000. In the 1990s, population decentralization became more obvious. During the period from 1982 to 1990,36 subdistricts lost population, while during the period from 1990 to 2000 , the number of such subdistricts amounted to 99 . In the 1980 s, these subdistricts were located in the core, and in the west of Mentougou District, which is a mountainous area. In the 1990 s, some subdistricts in the core that had lost population in the 1980s continued losing population. But many more subdistricts in the outer part of the metropolitan area began to lose population. Moreover, in the 1980s, the growth rates of 
Through suburbanization, population densities declined in the 1990s. The highest subdistrict population density decreased from 47,000 persons $/ \mathrm{km}^{2}$ in 1990 to less than 37,000 persons / $\mathrm{km}^{2}$ in 2000 . High density areas (more than 30,000 persons $/ \mathrm{km}^{2}$ ) extended outwards from the core to the inner suburbs. Figure $4 \mathrm{a}$ presents the population density in 2000 and Figure $4 \mathrm{~b}$ shows the changes in subdistrict population densities during the period from 1990 to 2000 . The subdistricts with population density decreasing by more than 1,000 persons $/ \mathrm{km}^{2}$ were located in the core, while subdistricts with population density increasing by more than 5,000 persons / $\mathrm{km}^{2}$ were in the inner suburbs.

The rapid growth of the inner suburbs may also be attributable to the incoming of migrant population. Table 2 shows that migrant population in the inner suburbs increased by $389 \%$ in the 1980s and by $407 \%$ in the 1990s. Consequently, the inner suburbs of Beijing saw fast growth of migrant population, which further exacerbated the 'urbanization of the suburbs'. However, narrowly defined 'suburbanization' only refers to the relocation of urban households to suburbs. Therefore we need to understand the impact of migrants on population distribution so as to identify the process of suburbanization of urban households. In the period from 1982 to 1990 the core lost $3.4 \%$ of its total population. But the decline of the permanently registered urban population reached $6.1 \%$. In the $1990 \mathrm{~s}$, the decline of the total population was $9.5 \%$ but the permanently registered population in the core declined by $18.2 \%$. In the inner suburbs of Beijing, the permanently registered population increased by 880,000 , while the total population increased by 1.150 million from 1982 to 1990 . In the 1990 s, the permanently registered population increased by 1.130 million and the total population by 2.400 million. 
Therefore, both in the 1980s and in the 1990s, permanently registered residents relocated outwards to the suburbs. Rapid inner suburban population growth is caused by not only the arrival of migrants but also by the relocation of urban households.

\section{New trends of suburbanization}

In this section we examine the recent trends of residential, industrial and retail suburbanization. The new elements of suburban built forms are listed in Figure 5.

\subsection{Residential suburbanization}

Real estate developers in the 1990 s began to promote the concept of suburbanization in housing development. They called on people who could afford high quality living to move out of the core to a more comfortable suburban environment, because the core had a very high population density, traffic jams and polluted air. The number of villa projects in Beijing amounts to about 160 , with more than 40,000 villa units. Villa customers are mainly affluent people, while affordable housing is theoretically for lower income households but in reality is sold to better-off households, i.e. middle class.

In recent years, the demand for townhouses has increased (Institute of Soufang, 2003). Most townhouses are built in the suburbs of Beijing, in consideration of the cheaper land prices. There were 80 villa projects on sale at the end of 2002, with most of them distributed in the north-east and north suburbs of Beijing, in particular near the north-east $4^{\text {th }}$ ring road and along the airport road, and in the area from the Asian Games Village to Haidian and Changping. The villa projects in the north-east and north suburbs of Beijing account for $65 \%$ of the total. Chaoyang has the greatest provision of villas. Of villas built from 1999 to $2003,98.3 \%$ were in the suburbs (65.9\% in the outer suburbs). In the outer suburbs, villas are mainly concentrated in Changping, Shunyi, Tongzhou and Daxing. Villas in southern suburbs tend to be closer to the inner suburbs (Figure 5).

The construction of affordable housing, a subsidized form of commodity housing (through 
Related to the suburbanization of the second home in the West (Pacione, 1984) is the attraction of suburbs as places for leisure and recreation. Today, many residents visit their second homes located in the suburbs for the weekend (Li, 2002). In Jingxia, a luxury residence near Miyun reservoir, about $70 \%$ of houses are used as second homes. With the emergence of the new rich (Hu \& Kaplan, 2001) and the development of the housing market (Huang \& Clark, 2002), better-off households also buy second homes as investment assets. Some are leased for a profit, while others are kept for use in extended holidays and as investments.

Major road improvements have contributed to suburbanization. By 1990 , the $2^{\text {nd }}$ and $3^{\text {rd }}$ ring roads had been completed, and by 2004 the $4^{\text {th }}$ and $5^{\text {th }}$ ring roads had been completed, with the $6^{\text {th }}$ ring road under construction. Since the 1990 s, more than 10 arterial roads radiating from the core to the suburbs in Beijing have greatly increased the accessibility of the suburbs, thus promoting suburbanization and the construction of villas and affordable housing in the suburbs. Private car ownership has also contributed to suburbanization since 1990. In the 1980s, those who could afford to buy cars in China were few and extremely rich, such as the owners of private enterprises, famous actors and actresses, and sports stars. There were only 1,107 private cars in Beijing in 1985 (Zhou, 1996). Since then, more and more people have bought private cars. In 2002, 12\% of all households in Beijing owned private cars (Wang, 2002). About 60\% of all cars in Beijing are privately owned (Wang, 2001). By July 2002, the number of cars in 
Beijing was about 1.8 million, of which the number of private cars was 1.1 million. In terms of transport mode, the percentage of private cars rose from 6\% to $18 \%$ between 1990 and 2002. By the end of 2005, Beijing's private motorized vehicles had reached 1.8 million, of which private cars amounted to 1.54 million (Table 3). Private cars did not play an important role in suburbanization in the 1980 s because of the low private ownership rate. However, in the 1990s, more and more commuters in Beijing began to use private cars.

Residential preferences have also changed. House prices in the core are much higher than in the suburbs, because the land in the central area is more expensive. For ordinary workers, moving to the suburbs becomes a practical way to improve housing conditions. Even for the rich and the middle class, villas or high-quality apartments in the suburbs become attractive, because the living environment there is better than in the central city. Residents were unwilling to move out of the core in the past, but in recent years there has been a popular saying about 'larger house, better life'.

Compared with suburbanization in the USA and other western economies, suburbanisation in China did not start from large-scale residential relocation. But increasingly, residential suburbanisation became an important driving force. To some extent, current residential suburbanisation shows both the feature of residential suburbanisation in the 1960s in the USA and also more fragmented and exclusive gated communities development nowadays.

\subsection{Industrial decentralization}

Since the 1990s, Beijing's industrial suburbanization has accelerated. In terms of land use, the proportion of industrial land use experienced a 4\% decline from 1987 to 1995 . From 1985 to 1997, about 59.23 ha of land were vacated due to the moving of industrial enterprises, of which $71 \%$ was from the core. From 1995 to $1999,171.8$ ha of land were unoccupied because of industrial relocation, especially of polluters or enterprises that disturbed local residents (Yu, 1999; $\mathrm{Wu}, 2000)$. The proportion of industrial land use within the $4^{\text {th }}$ ring road decreased from $8.74 \%$ to $7.26 \%$ between 1999 and 2002. As a result, the Planning of Adjustment of Industrial 
Distribution in Beijing in 2002 specified a target of $7 \%$ of industrial use in 2005, but the figure was reached in advance. In 2005, Beijing planned to move more than 150 industrial enterprises out of the municipality, vacating land of 900 ha, with the proportion of industrial land use in the built-up area falling to less than 6.6\% (Wang, 2002; Zhu, 2002).

Industrial decentralization is due to a number of reasons. First, the moving and renovation of polluting industrial enterprises accelerated in the 1990s because of the need to achieve a better environmental quality. The Beijing government needs to meet the requirements of the 'Green Olympic Games' in 2008 and has thus accelerated industrial relocation.

Second, the land leasing system was established in the 1990s. Prior to the 1990s, compensatory payments for enterprise relocation were much lower because there was no land market in urban China. Only after 1992, when Beijing began to evaluate the price of urban land, did compensatory payments increase significantly. From 1985 to 1995, the compensatory payment for moving in Beijing was 1.178 billion Yuan, while from 1995 to 2000 it was 12.07 billion Yuan. With the land leasing system, relocated enterprises can obtain more money from land transfer to support their moving and redevelopment. In fact, since the 1990s, industrial suburbanization has not been confined to the moving of polluting enterprises. Some non-polluting industrial enterprises have also moved so as to get land payments.

Third, industrial enterprises use relocation to obtain more space and adjust their products through technological innovation using money from land transfer. A good example is Beijing's asphalt and concrete factory, located in the Asian Games Village. In 1997, the factory moved to Changping, an area in the outer suburbs. The money from the land transfer made it possible for the factory to buy an advanced production line from the US and Japan. The problem of pollution from noise and dust was solved. Moreover, the factory improved its products after moving, bringing more profit. Many industrial enterprises began to move actively in the 1990s in order to take advantage of the opportunity for innovation and redevelopment.

Fourth, industrial decentralization is also a requirement of urban plans. The master plan of 
Beijing in 1983 requires that polluting industrial enterprises in the core or within the $3^{\text {rd }}$ ring road should stop production and move out. In 1988, the Beijing planning department listed about 100 enterprises to be relocated. In the 1990s, the plan accelerated industrial decentralization.

Fifth, the construction of development zones also stimulates industrial suburbanization. Since 199028 development zones have been built in Beijing, among which three are at the national level and eighteen at the municipal level. The land for development zones adds up to $90.1 \mathrm{~km}^{2}$, with a total investment of 397.3 billion Yuan and accumulated contracted foreign capital of 9.05 billion Yuan (Beijing Statistics Bureau, 2005). All the development zones are located in the suburbs (Figure 5). Some larger zones develop more zones further out in the suburbs. For example, Zhongguancun Science Park now includes seven parks such as Haidian Park, Fengtai Park, Changping Park, and Yizhuang Park. Since 1990 industrial enterprises have been attracted by favourable policies in development zones and have chosen to relocate to these development zones.

Compared with post-industrial suburbanization in the West, Chinese cities are still in the stage of industrialization. The development of industrial parks and zones accommodates both manufacturing and services industries.

\subsection{Retail suburbanization}

Large supermarkets appeared in China in 1995 and have developed rapidly since 1998. Since the mid-1990s, the retail sector in Beijing's core has reached saturation point, not only with less space for further development, but also with increasing competition. Most of the large department stores have narrow profit margins, and some of them have incurred losses since 1997. Under such circumstances, many larger shopping centres have been developed in the suburbs, changing the spatial pattern of the traditional retail sector. Thus, commercial suburbanization has manifested itself in Beijing since the late 1990s. 
In Beijing, the gross sales of supermarkets comprised $12 \%$ of total gross retail sales in 2000 (Beijing's Committee of Development and Planning, 2001). Figure 5 shows the distribution of large shopping centres in Beijing in 2002. Most large shopping centres are located outside the core. The core makes up only $25 \%$ of the total. The Beijing government has begun to control the development of supermarkets in the core. The Tenth Five Year Plan (2000-2005) stated that large shopping centres with an area of more than $10,000 \mathrm{~m}^{2}$ should be located outside the $3^{\text {rd }}$ ring road and that no new large department stores should be developed within the $2^{\text {nd }}$ ring road (Beijing's Committee of Development and Planning, 2001). Consequently, commercial suburbanization has been accelerated in Beijing.

Several factors have contributed to the development of suburban shopping centres. First, cheaper prices and a greater variety of goods are a main attraction. Producers supply goods directly to the supermarkets, shortening intermediate links and reducing the costs. Supermarkets often sell goods first and pay the producers later, bringing great advantages to the supermarkets. As a result, it is possible to reduce the prices of commodities. Moreover, a greater variety of goods is available in large suburban supermarkets. Residents can satisfy their needs without going into the city.

Second, the suburbs can provide cheaper land, meeting the need for the construction of storage space and large car parks. In Beijing, the business area of large supermarkets often increases from 2,500 to $10,000 \mathrm{~m}^{2}$, and that of hypermarkets, which appeared several years ago in Beijing, has increased from 7,000 to $12,000 \mathrm{~m}^{2}$. In some large supermarkets, $60 \%$ of the space is used for storage and wholesale of goods. Large car parks are built, convenient for car users. The Golden Resources Shopping Mall (Figure 6), located in Haidian, near the north-western $4^{\text {th }}$ ring road, required an investment of 3.8 billion Yuan. It opened for business in 2004 and has a floor space of $680,000 \mathrm{~m}^{2}$, larger than West Edmonton Mall in Canada, the largest in Western countries. In order to attract car users, the Golden Resources Shopping Mall constructed underground and above-ground car parks with 10,000 parking spaces.

Third, residential suburbanization in the 1990s stimulated retail suburbanization. New 
residential quarters have been developed outside the $4^{\text {th }}$ ring road. The rising demand for shopping facilities in the suburbs has led to the construction of large shopping malls. But once the shopping mall has been constructed, it attracts further housing development around it. For example, around the Golden Resources Shopping Mall residential quarters such as Century City, Shuguang Garden and Zizhu Garden have been built, with 400,000 residents relocating there.

Fourth, since China became a member of the World Trade Organization in 2001, global retail companies have selected Beijing to build stores. Today, most of the 50 largest retail companies in the world have entered China. In Beijing, more than ten international retail companies, such as Carrefour, Wal-Mart, METRO, Auchan, Lotus Supercenter, B\&Q, Pricesmart, etc., have financed and constructed stores in the suburbs, called foreign supermarkets ('yang chaoshi'). With a powerful global purchasing system and an advanced network of goods flow management, it is possible for 'yang chaoshi' to greatly reduce their costs and conduct a strategy of dumping at low prices, attracting more and more customers. Figure $6 \mathrm{~b}$ shows the flow of customers over one weekend in one of the Carrefour stores in Beijing, located in Zhongguancun, the electronics market and high-tech agglomeration (Wang \& Wang, 1998).

To sum up, cheaper land, available consumers and the inflow of global retail companies have promoted the development of suburban shopping centres and retail parks in Beijing. The rising suburban retail sector has not led to the decay of retail in the core. This is different from residential and industrial suburbanization, which has led to the decline of population and industries in the core. Retail in the core remains steady and is still flourishing. The development of large suburban shopping centres is both the cause and outcome of suburbanization. With residential suburbanization, large shopping centres are needed to satisfy suburban shopping demand. On the other hand, with the improvement of shopping facilities in the suburbs, more and more people choose to move to the suburbs, without worrying about the lack of living facilities, which promotes further residential suburbanization.

Suburbanization has implications for commuting and social distribution. The first and foremost 
consequence is the extended commuting distance. With industrial suburbanization, there are more and more commuters in Beijing. When enterprises move out of the core to the suburbs, most of the employees remain in the city and thus have a longer commuting distance, putting tremendous pressure on urban traffic. The Third Factory of Medicine of Beijing is a good example. In 1995, the factory moved out of the core to Shuangqiao, located in the outer fringe of Chaoyang, because of the lack of development space. Almost all of the employees, about 400 to 500 , have to work at Shuangqiao but live in the core. As a result, the factory has to use ten coaches to transport their employees, costing the factory about three million Yuan every year.

Today, the suburbs are no longer dominated by the city centre and have begun to compete with it. The dependence of residents on the city centre for shopping is declining. Suburban residents mostly use large shopping malls to satisfy their shopping needs.

The new round of suburbanization has led to changing social composition in the suburbs. The suburbs are now more heterogeneous. Commodity housing and affordable housing projects constructed in the suburbs have led to the residential relocation of both better-off and lower-income residents. Moreover, migrants have also begun to concentrate in the inner suburbs (Feng, 2004; Feng \& Zhou, 2005; Gu \& Kesteloot, 1997). At the same time, the new rich live in villas and gated communities in the suburbs (Hu \& Kaplan, 2001; Wu, 2005). The concentration of better-off residents, ordinary workers, poor migrants, and the newly affluent in addition to existing farmers in the suburbs makes the social composition of suburbs very complicated.

Compared with ‘new suburbanization’ (Stanback 1991), Chinese retail suburbanisation is only at an initial stage. In terms of distribution of retail, the city has not reached the stage of 'turning inside out'. The commercial centres in the central areas are still very attractive and dominate the landscape of retailing. 


\section{Conclusion}

The objective of this paper is to use newest data to identify some new trends in Beijing since 1990 and in turn to speculate on similarities and differences of suburbanization in China and in other Western economies. To be sure, the extent of suburbanization varies from country to country, even within Western market economies. Beijing's suburbanization, when compared with its process in the 1980s, has shown some interesting trends.

In the 1980 s, residential suburbanization was for the most part passive. The relocation of residents was caused by housing rehabilitation in the urban core. During the course of rehabilitation, residents were moved out to suburban housing estates planned and financed by the government. Since 1990, the development of a market economy has led to a flourishing real estate market. Many developers have actively participated in the construction of suburban housing. The price difference between the suburbs and core urban areas has widened. The core urban area has house prices two or three times above those of the suburbs. Residents began to choose suburban locations taking into account the house price difference and environmental quality.

Industrial suburbanization has seen the effect of the market mechanism since 1990. Land reform has opened up the land market, promoting the decentralization of industry. More and more factories in the urban core have moved out to the suburbs. While the role of government is still present in industrial suburbanization in Beijing, industrial relocation is made possible by differentiated land prices. In order to reduce environmental pollution, the government uses the price difference to relocate factories. The approach of the 2008 Olympic Games is speeding up industrial relocation. The policy of economic development zones and high-tech industrial parks in the suburbs makes industrial location more attractive.

The construction of shopping centres in Beijing's suburbs is mainly driven by commercial investment, including domestic retailers such as Chaoshifa, Hualian and Wumei companies and foreign retail groups such as Carrefour, Wal-Mart and METRO. These shopping malls follow the decentralization of population and increasing demand in the suburbs. The trend of 
commercial decentralization became more apparent in the 1990s, with both domestic and international enterprises entering the commercial market in Beijing.

Suburbanization in advanced market economies has seen new features and new developments such as edge cities (Garreau, 1991), suburban magnet areas (Stanback, 1991) and suburban employment centres (McDonald \& Prather, 1994; McDonald, 2000; Small \& Song, 1994). China's suburbanization began from a very different starting point (Zhou \& Ma, 2000). The rationale was more based on the government policy of decentralizing congested old urban areas. However, with the deepening of market reform, Beijing has seen a new round of suburbanization, which is more based on the market mechanism. With growing private car ownership, increasing house price differences and changing residential preferences, more and more residents are seeking suburban living; industrial relocation occurs because of land use adjustment and the construction of suburban industrial parks; and large-scale suburban shopping malls attract more and more people in both suburbs and urban areas.

Despite the growing role of market forces, given the role of government, the development of public transportation, and the size and density of population, it is unlikely that Beijing's suburbanization will reach the extreme extent of North American cities. While there are some similarities, Beijing's suburbanization is not an identical process. There are two differences. First, Beijing is still at an early stage of suburbanization. Average household income is still low, and the use of private cars is not comparable to the case in North American cities. Second, the government is still playing an important role in suburbanization. Very often the government tends to use the land market to achieve its objectives. For example, the land market gives the local government a strong incentive to sell land in the suburbs (Zhang, 2000). Beijing's suburbs are far from being independent cities or 'stealth political entities' (Knox, 1993). The new master plan of Beijing approved in 2005 began to use the concept of polycentric structure to promote the decentralization of population and employment. In short, Beijing has entered a new stage of suburbanization, but the exact form of suburbanization is still influenced heavily by public policies. 
To conclude, at the initial stage of suburbanization in China, the government played a major role in suburban industrial relocation and suburban development because it controlled industrial, land and housing development. Accordingly, suburbanization in China before 1990 should be described as 'government-led'. However, market mechanisms were introduced into suburbanization after 1990. Without doubt, the new round of suburbanization in Beijing is more market-oriented. While we are not arguing that Beijing's suburbanization converges on the trend that has been seen in the West, recent suburbanization processes in Beijing do show a pattern mixed with both the newest development (such as retail parks and edge cities) as well as traditional suburban residential relocation driven by mass consumption.

\section{Reference}

Beijing's Committee of Development and Planning, 2001. Plan of the development of commerce in Beijing in the Tenth Five Year Plan (in Chinese).

Beijing's Census Office, 1982. Manually Tabulated Data of the Third Population Census of Beijing (in Chinese).

Beijing's Census Office, 1990. Manually Tabulated Data of the Fourth Population Census of Beijing (in Chinese).

Beijing's Census Office, 2000. Manually Tabulated Data of the Fifth Population Census of Beijing (in Chinese).

Beijing Planning Committee, 1983. City Master Plan for Beijing (1981-2000). Beijing, China (in Chinese).

Beijing Planning Committee, 1993. City Master Plan for Beijing (1991-2010). Beijing, China (in Chinese).

Beijing Statistics Bureau, 1985-2002, 2003a, 2004a, and 2005. Beijing Statistical Yearbooks (1984-2004). Beijing: The Press of Chinese Statistics (in Chinese).

Beijing Statistics Bureau, 2003b \& 2004b, 2006. Beijing Area Statistical Yearbooks (2003 \& 2004, 2006). Beijing: Tongxin Press (in Chinese).

Bier, T., and Howe, S. R., 1998. Dynamics of suburbanization in Ohio metropolitan areas. Urban Geography, 19, 695-713.

Bontje, M., 2001. Dealing with deconcentration: population deconcentration and planning 
response in polynucleated urban regions in North-west Europe. Urban Studies, 38, 769-785.

Cadwallader, M. T., 1985. Analytical Urban Geography: Spatial Patterns and Theories. Englewood Cliffs, NJ: Prentice-Hall.

Cadwallader, M. T., 1996. Urban Geography: An Analytical Approach. Upper Saddle River, NJ: Prentice-Hall.

Castells, M., 1989. The Informational City: Information Technology, Economic Restructuring, and the Urban-Regional Process. Oxford, NY: Blackwell.

Champion, A. G., 2001. A changing demographic regime and evolving polycentric urban regions: consequences for the size, composition and distribution of city populations. Urban Studies, $38,657-677$.

Champion, T., 2001. Urbanization, suburbanization, counterurbanization and reurbanization. In R. Paddison, (ed.), Handbook of Urban Studies, London: Sage Publications, 143-161.

Coffey, W. J., 2000. The geographies of producer services. Urban Geography, 21, 170-183.

Coffey, W. J., and Shearmur, R. G., 2001. Intrametropolitan employment distribution in Montreal, 1981-1996. Urban Geography, 22, 106-129.

Coffey, W. J., and Shearmur, R. G., 2002. Agglomeration and dispersion of high-order service employment in the Montreal metropolitan region, 1981-96. Urban Studies, 39, 359-378.

Coffey, W. J., Drolet, R., and Polèse, M., 1996. The intrametropolitan location of high order services: patterns, factors and mobility in Montreal. The Journal of Regional Science Association International, 75, 293-323.

De Vise, P., 1976. The suburbanization of jobs and minority employment. Economic Geography, $52,348-363$.

Fan, C. C., 2001. Migration and labor-market returns in urban China: Results from a recent survey in Guangzhou. Environment and Planning A, 33, 479-508.

Fan, C. C., 2002. The elite, the natives, and the outsiders: Migration and labor market segregation in Urban China. Annals of the Association of American Geographers, 92, 103-124.

Feng, J., 2004. Restructuring of Urban Internal Space in China in the Transition Period. Beijing, China: Science Press (in Chinese).

Feng, J., and Zhou, Y. X., 2005. Suburbanization and the changes of urban internal spatial structure in Hangzhou, China. Urban Geography, 25, 107-136. 
Feng, J., and Zhou, Y. X., 2004. Intra-urban migration and correlative spatial behavior in Beijing in the process of suburbanization: based on 1,000 questionnaires. Geographical Research, 23, 227-242 (in Chinese).

Gad, G., 1985. Office location dynamics in Toronto: Suburbanization and central district specialization. Urban Geography, 6, 331-351.

Garreau, J., 1991. Edge City. New York, NY: Doubleday.

Graves, P. E., 2003. Nonoptimal levels of suburbanization. Environment and Planning A, 35, 191-198.

Gu, C. L., and Kesteloot, C., 1997. The spatial differentiation and social polarization in Beijing. Acta Geographica Sinica, 52, 385-393 (in Chinese).

Gu, C. L., Wang, F. H., and Liu, G. L., 2005. The structure of social space in Beijing in 1998: a socialist city in transition. Urban Geography, 25, 167-192.

Hall, P., 1984. The World Cities. New York, NY: St. Martin's Press.

Hu, X. H., and Kaplan, D. H., 2001. The emergence of affluence in Beijing: residential social stratification in China's capital city. Urban Geography, 22, 54-77.

Huang, Y., and Clark, W. A. V., 2002. Housing tenure choice in transitional urban China: a multilevel analysis. Urban Studies, 39, 7-32.

Institute of Soufang, 2003. Review on the market of villa in Beijing, The Economic Observer, 22 December (in Chinese).

Jackson, K. T., 1985. Crabgrass Frontier: The Suburbanization of the United States. Oxford, NY: Oxford University Press.

Jing, T. H., Deng, X. G., and Yu, X. Q., 2001. Report on the development of China Capital in 2001. Beijing: Press of Social Science Literature, 2001 (in Chinese).

Johnson, J. H., 1974. Suburban Growth: Geographical Processes at the Edge of the Western City. London: J. Wiley.

Jordan, S. et al., 1998. U.S. Suburbanization in the 1980s. Regional Science and Urban Economics, 28, 611-627.

Knox, P. 1993. The Restless Urban Landscape. Englewood Cliffs, NJ: Prentice-Hall.

Li, S. M., 2001. Residential mobility and urban restructuring under market transition: a study of Guangzhou, China. Professional Geography, 53(2), 219-229. 
Li, S. M., 2000. Housing consumption in urban China: a comparative study of Beijing and Guangzhou. Environment and Planning A, 32, 1115-1134.

Li, X. F., 2002. Second home manifests itself in Beijing. Beijing Daily, 14 February (in Chinese). Lo, C. P., 1994. Economic reforms and socialist city structure: a case study of Guangzhou, China. Urban Geography, 15(2), 128-149.

Logan, J. R., Bian, Y. J., and Bian F. Q., 1999. Housing inequality in urban China in the 1990s. International Journal of Urban and Regional Research, 23 (1): 7-25.

Logan, J. R., 2001. The Chinese City: Globalization and Market Reform. Oxford: Blackwell.

Lu, C., 2002. The number of private automobiles is 7,710 thousand. Beijing Youth, 8, November (in Chinese).

Ma, L. J. C. and Cui G. H., 1987. Administrative changes and urban population in China. Annals of the Association of American Geographers, 77, 373-395.

McDonald, J. F., 2000. Employment subcenters and subsequent real estate development in suburban Chicago. Journal of Urban Economics, 48, 135-157.

McDonald, J. and Prather, P., 1994. Suburban employment centers: The case of Chicago. Urban Studies, 31, 201-218.

Ning, Y. M., and Yan, Z. M., 1995. The changing industrial and spatial structure in Shanghai. Urban Geography, 16, 577-594.

Pacione, M., 1984. Rural Geography. New York: Harper \& Row.

Palen, J. J., 1997. The Urban World, NY: The McGraw-Hill Companies, Inc.

Scott, A. J., 1982. Locational patterns and dynamics of industrial activity in the modern metropolis. Urban Studies, 19, 111-141.

Sit, V. F. S., 1995. Beijing: The Nature and Planning of a Chinese Capital City. New York: John Wiley \& Sons.

Small, K. A., and Song, S., 1994. Population and employment densities: structure and change. Journal of Urban Economics, 36, 292-313.

Stanback, T. M., Jr., and Knight, R., 1979. Suburbanization and the City. Montclair, NJ: Allanheld, Osmun \& Co. Publishers.

Stanback, T. M., 1991. The New Suburbanization. Boulder, CO: Westview.

Sun, Y. S., 1992. The developmental process and the judgement of metropolis: a case study of 
Beijing. Acta Geographica Sinica, 47 (6), 552-560 (in Chinese).

Wang, F. H., and Zhou, Y. X., 1999. Modeling urban population densities in Beijing 1982-1990: Suburbanization and causes. Urban Studies, 36, 263-279.

Wang, J. C., and Wang, J. X., 1998. An analysis of new-tech agglomeration in Beijing: a new industrial district in the making? Environment and Planning A, 30, 681-701.

Wang, J. H., 2002. The number of private automobiles exceeds that of public ones, with 12 per cent of the total families having private automobiles. Beijing Evening, 26 February (in Chinese).

Wang, J. X., 2002. The moving of the industrial enterprises in Beijing is so busy. China Daily, 3 June (in Chinese).

Wang, X., 2001. What does the new policy of automobile consumption bring us? Beijing Youth, 12 August (in Chinese).

Wang, Y. P., and Murie, A., 1999. Commercial housing development in Urban China. Urban studies, 36, No. 9, 1475-1494.

Wu, F., 2005. Rediscovering the 'gate' under market transition: from work-unit compounds to commodity housing enclaves. Housing Studies, 20, 235-254.

$\mathrm{Wu}$, J., 2000. The planning and distribution of industry in Beijing. The Planning and Construction of Beijing, (5), 33-35 (in Chinese).

Yeh, A. G. O., Xu, X. Q., and Hu, H. Y., 1995. The social space of Guangzhou City, China. Urban Geography, 16, 595-621.

Yeh, A. G. O., and Wu, F., 1995. Internal structure of Chinese cities in the midst of economic reform. Urban Geography, 16, 521-554.

Yu, T. Z., 1999. The adjustment of industrial structure and the distribution of industrial land use in Beijing. The Planning and Construction of Beijing, (3), 48-50 (in Chinese).

Zhang, T. W., 2000. Urban sprawl in China: land market force and government's role. Cities, 17(1): 123-135.

Zhang, J. X. and Wu, F., 2006. China's changing economic governance: administrative annexation and the reorganization of local governments in the Yangtze River Delta. Regional Studies, 40(1): 3-21.

Zhou, Y. X., 1996. Beijing's suburbanization and some related thoughts. Scientia Geographica 
Sinica, 16, 198-206 (in Chinese).

Zhou, Y. X., and Ma, L. J. C., 2003. China's urbanization levels: Reconstructing a baseline from the fifth population census. The China Quarterly, 173, 176-196.

Zhou, Y. X., and Ma, L. J. C., 2000. Economic restructuring and suburbanization in China. Urban Geography, 21, 205-236.

Zhou, Y. X., and Meng, Y. C., 2000. On Beijing's suburbanization and its countermeasures. Beijing: Science Press (in Chinese).

Zhu, Y., 2002. Forty industrial enterprises have moved out of the $4^{\text {th }}$ Ring in Beijing recently. Beijing Youth, 30 October (in Chinese).

Zong, Y. G. et al., 2002. The multiplier effect and growth model of the development of land in Beijing metropolis. Geographical Research, 21, $89-96$ (in Chinese). 
Table 1. Population changes in different zones in Beijing, 1982 to 1990 and 1990 to 2000

\begin{tabular}{|c|c|c|c|c|c|c|c|}
\hline \multirow{2}{*}{\multicolumn{2}{|c|}{$\begin{array}{l}\text { Population changes } \\
\text { in different period }\end{array}$}} & \multirow{2}{*}{$\begin{array}{c}\text { City } \\
\text { region } \\
\text { total }\end{array}$} & \multirow[b]{2}{*}{ Core } & \multirow{2}{*}{$\begin{array}{l}\text { Inner } \\
\text { suburbs }\end{array}$} & \multicolumn{3}{|c|}{ Outer suburbs } \\
\hline & & & & & Level one & Level two & Total \\
\hline \multirow{3}{*}{ 1982-1990 } & $\begin{array}{l}\text { Number change } \\
\text { (thousand persons) }\end{array}$ & 158.9 & -8.2 & 114.9 & 37.9 & 14.2 & 52.1 \\
\hline & Per cent change $(\%)$ & 17.21 & -3.38 & 40.46 & 13.69 & 11.82 & 13.12 \\
\hline & $\begin{array}{l}\text { Annual per cent change } \\
(\%)\end{array}$ & 2.00 & -0.43 & 4.34 & 1.62 & 1.41 & 1.55 \\
\hline \multirow{3}{*}{ 1990-2000 } & $\begin{array}{l}\text { Number change } \\
\text { (thousand persons) }\end{array}$ & 275.0 & -22.2 & 240.0 & 53.2 & 4.0 & 57.2 \\
\hline & Per cent change $(\%)$ & 25.42 & -9.50 & 60.15 & 16.93 & 2.94 & 12.73 \\
\hline & $\begin{array}{l}\text { Annual per cent change } \\
(\%)\end{array}$ & 2.29 & -0.99 & 4.82 & 1.58 & 0.29 & 1.21 \\
\hline
\end{tabular}

Notes: Level one of outer suburbs in Beijing refers to the outer suburbs within the metropolitan area, including 6 districts/counties, i.e., Mentougou, Fangshan, Tongzhou, Shunyi, Changping District and Daxing County. Level two of outer suburbs in Beijing refers to the outer suburbs out of the metropolitan area, including 4 counties, i.e., Pinggu, Huairou, Miyun and Yanqing counties.

Sources: Calculated from Beijing's Census Office (1982, 1990 and 2000). 
Table 2. The growth of permanently registered population and migrant population of different zones in Beijing, 1982 to 1990 and 1990 to 2000

\begin{tabular}{|c|c|c|c|c|c|}
\hline & Core & Inner suburbs & Outer suburbs & $\begin{array}{c}\text { Metropolitan } \\
\text { Area } \\
\end{array}$ & $\begin{array}{c}\text { City region } \\
\text { total }\end{array}$ \\
\hline \multicolumn{6}{|l|}{ I. Number of permanently } \\
\hline \multicolumn{6}{|l|}{ registered population (person) } \\
\hline 1982 & $2,354,247$ & $2,770,969$ & $3,923,024$ & $7,851,025$ & $9,048,240$ \\
\hline 1990 & $2,210,751$ & $3,647,503$ & $4,310,173$ & $8,852,842$ & $10,168,427$ \\
\hline 2000 & $1,807,574$ & $4,778,430$ & $4,375,997$ & $9,676,690$ & $10,962,001$ \\
\hline \multicolumn{6}{|l|}{ II. Change of permanently } \\
\hline \multicolumn{6}{|l|}{ registered population from 1982} \\
\hline \multicolumn{6}{|l|}{ to 1990} \\
\hline Number change (person) & $-143,496$ & 876,534 & 387,149 & $1,001,817$ & $1,120,187$ \\
\hline Per cent change $(\%)$ & -6.1 & 31.63 & 9.87 & 12.76 & 12.38 \\
\hline Annual per cent change $(\%)$ & -0.78 & 3.5 & 1.18 & 1.51 & 1.47 \\
\hline \multicolumn{6}{|l|}{ III. Change of permanently } \\
\hline \multicolumn{6}{|l|}{ registered population from 1990} \\
\hline \multicolumn{6}{|l|}{ to 2000} \\
\hline Number change (person) & $-403,177$ & $1,130,927$ & 65,824 & 823,848 & 793,574 \\
\hline Per cent change $(\%)$ & -18.24 & 31.01 & 1.53 & 9.31 & 7.8 \\
\hline Annual per cent change $(\%)$ & -1.99 & 2.74 & 0.15 & 0.89 & 0.75 \\
\hline \multicolumn{6}{|l|}{ IV. Number of migrant } \\
\hline \multicolumn{6}{|l|}{ population (person) } \\
\hline 1982 & 57,446 & 63,830 & 48,582 & 161,096 & 169,858 \\
\hline 1990 & 107,447 & 312,002 & 182,682 & 569,201 & 602,131 \\
\hline 2000 & 296,675 & $1,582,077$ & 688,973 & $2,465,005$ & $2,567,725$ \\
\hline \multicolumn{6}{|l|}{ V. Change of migrant } \\
\hline \multicolumn{6}{|l|}{ population from 1982 to 1990} \\
\hline Number change (person) & 50,001 & 248,172 & 134,100 & 408,105 & 432,273 \\
\hline Per cent change $(\%)$ & 87.04 & 388.8 & 276.03 & 253.33 & 254.49 \\
\hline Annual per cent change (\%) & 8.14 & 21.94 & 18.01 & 17.09 & 17.14 \\
\hline \multicolumn{6}{|l|}{ VI. Change of migrant } \\
\hline \multicolumn{6}{|l|}{ population from 1990 to 2000} \\
\hline Number change (person) & 189,228 & $1,270,075$ & 506,291 & $1,895,804$ & $1,965,594$ \\
\hline Per cent change $(\%)$ & 176.11 & 407.07 & 277.14 & 333.06 & 326.44 \\
\hline Annual per cent change $(\%)$ & 10.69 & 17.63 & 14.2 & 15.79 & 15.61 \\
\hline
\end{tabular}

Sources: Calculated from Beijing's Census Office (1982, 1990 and 2000). 
Table 3. The increase of private motor vehicles in Beijing

\begin{tabular}{|l|r|}
\hline Year & Private motor vehicles \\
\hline 1987 & 7148 \\
\hline 1989 & 24029 \\
\hline 1992 & 48643 \\
\hline 1993 & 66883 \\
\hline 1994 & 85474 \\
\hline 1995 & 127568 \\
\hline 1996 & 351835 \\
\hline 1997 & 540564 \\
\hline 1998 & 697707 \\
\hline 1999 & 762361 \\
\hline 2000 & 855321 \\
\hline 2001 & 1004830 \\
\hline 2002 & 1195060 \\
\hline 2003 & 1389569 \\
\hline 2004 & 1546865 \\
\hline 2005 & 1798407 \\
\hline
\end{tabular}

Note: private motor vehicles includes private motors and private cars. For example, in 2005 , there were 1.80 million private motor vehicles, of which 1.54 million were private cars.

Source: Beijing Statistical Bureau (2006: 281). 


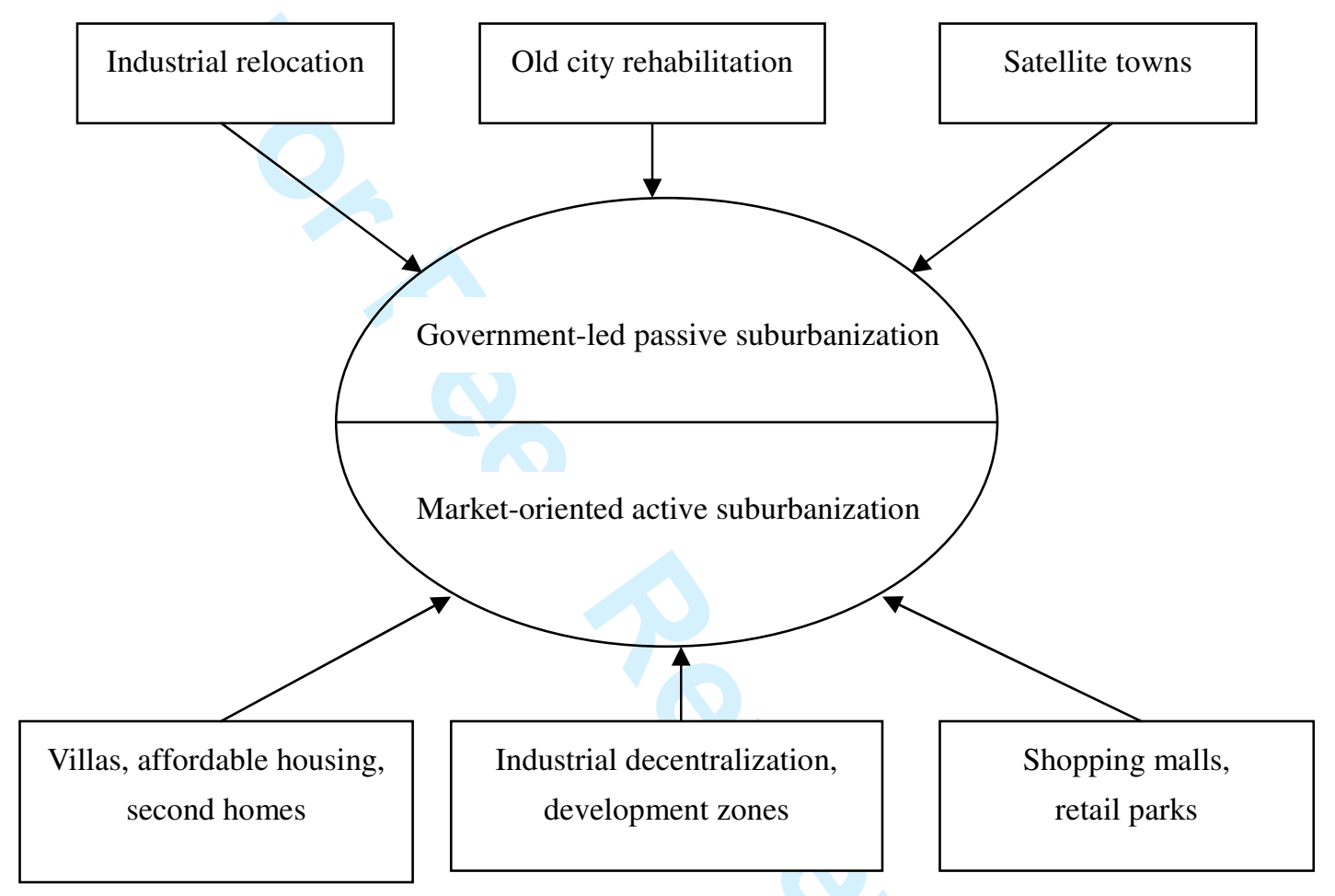

Figure 1 The change of suburbanization from government-led passive to market-oriented active in Beijing 


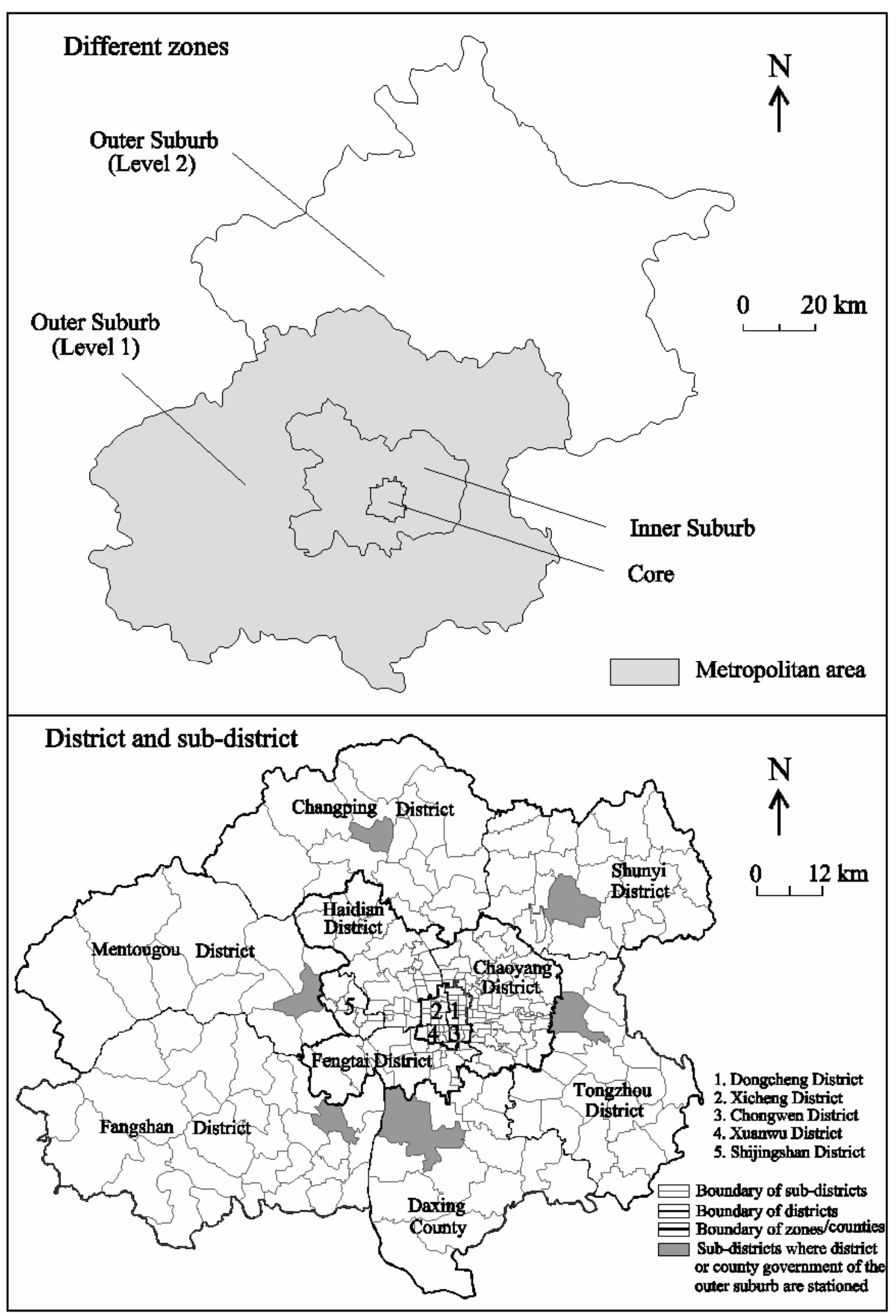

Figure 2 Spatial concepts in Beijing 


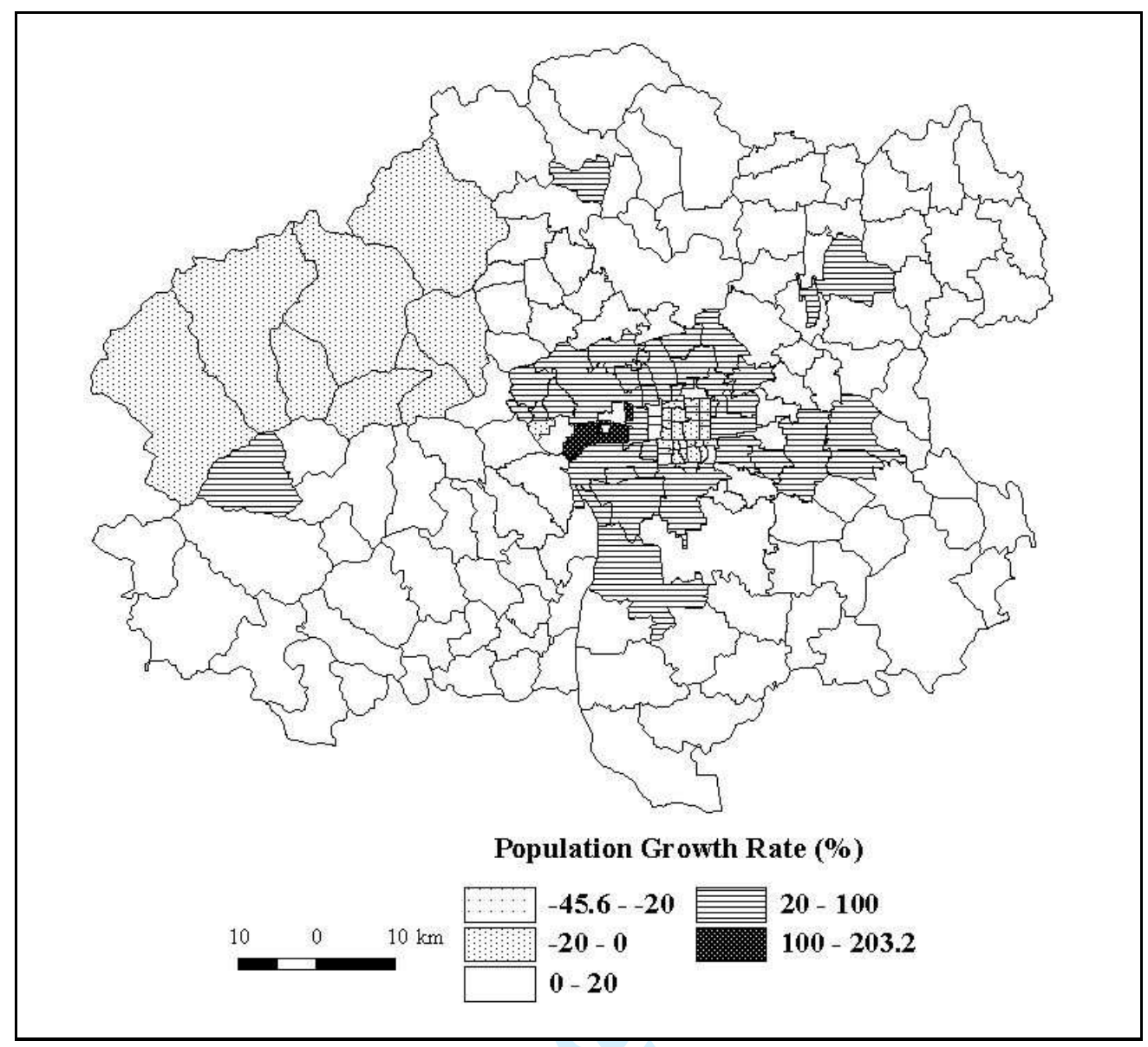

Figure 3a The spatial distribution of population growth rates in Beijing by subdistrict, 1982 to 1990

Sources: Calculated from Beijing's Census Office (1982 and 1990). 
Figure 3b The spatial distribution of population growth grates in Beijing by subdistrict, 1990 to 2000

Sources: Calculated from Beijing's Census Office (1990 and 2000). 


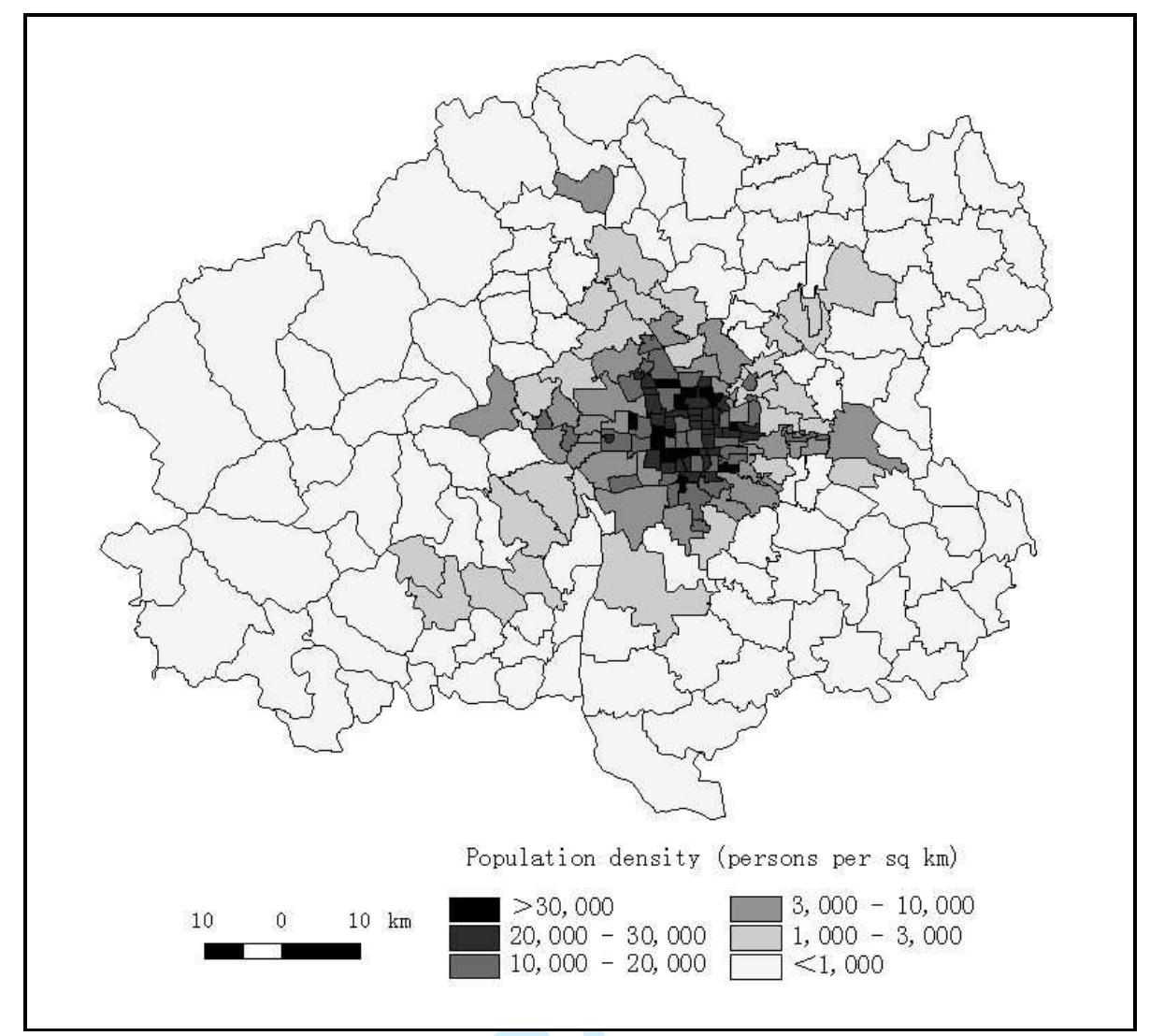

Figure 4a The spatial distribution of population density in Beijing by subdistrict in 2000

Source: Calculated from Beijing's Census Office (2000). 


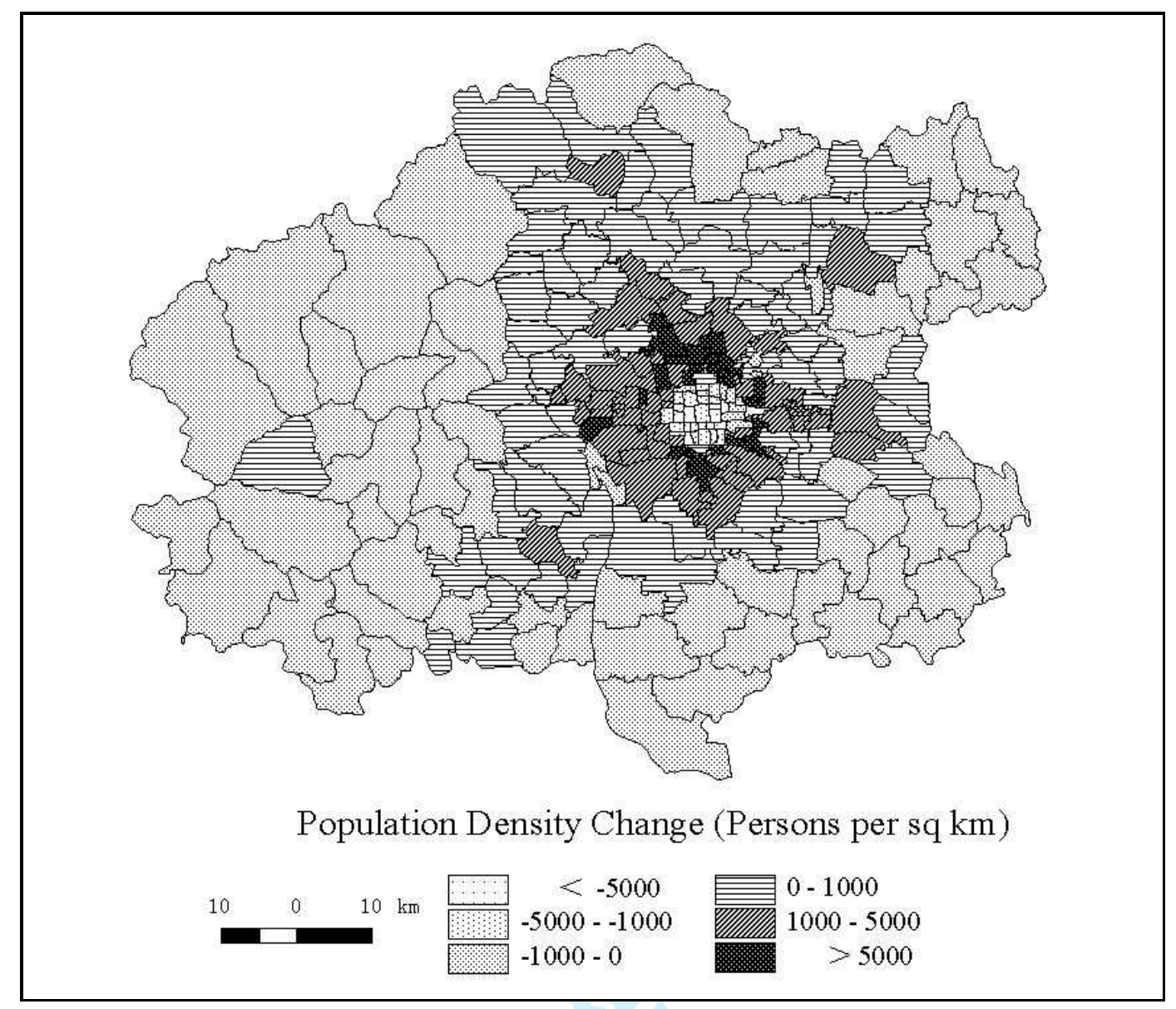

Figure $\mathbf{4 b}$ The spatial distribution of population density changes in Beijing by subdistrict, 1990 to 2000

Sources: Calculated from Beijing's Census Office (1990 and 2000). 


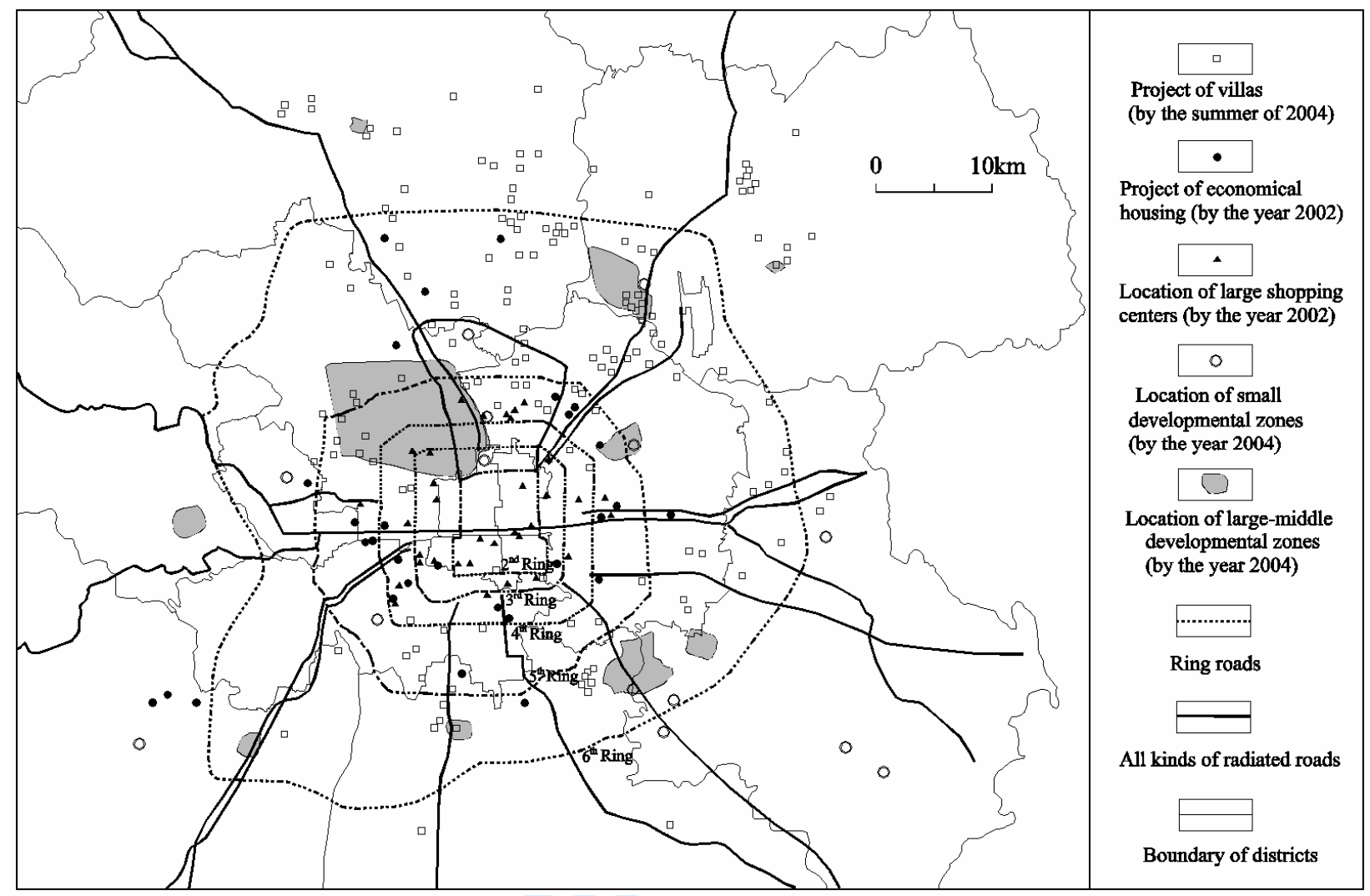

Figure 5 The spatial distribution of villas, affordable housing projects, large shopping centres and development zones in Beijing 


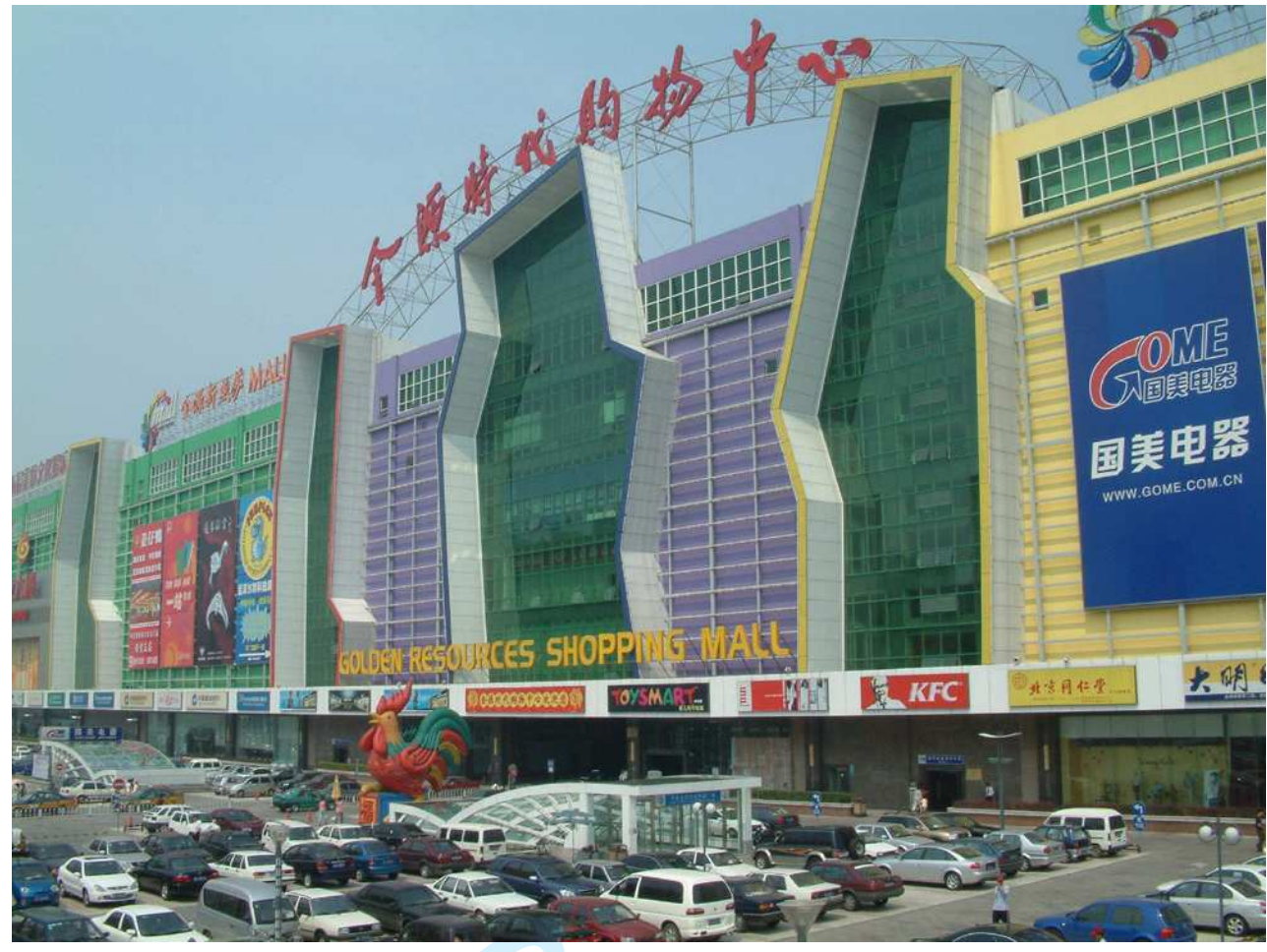

Figure 6 The Golden Resources Shopping Mall in Beijing 